Tropical Journal of Pharmaceutical Research January 2017; 16 (1): 119-125

ISSN: 1596-5996 (print); 1596-9827 (electronic)

(c) Pharmacotherapy Group, Faculty of Pharmacy, University of Benin, Benin City, 300001 Nigeria.

All rights reserved.

Available online at http://www.tjpr.org

Original Research Article

http://dx.doi.org/10.4314/tjpr.v16i1.15

\title{
Preventive role of Withania somnifera on hyperlipidemia and cardiac oxidative stress in streptozotocin induced type 2 diabetic rats
}

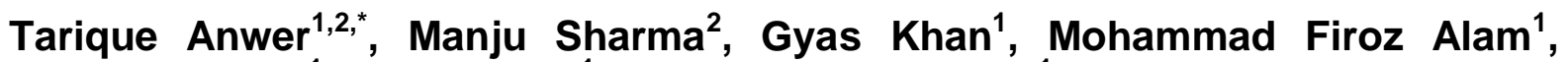 \\ Nawazish Alam ${ }^{1}$, Md Sajid Ali ${ }^{1}$ and Md Sarfaraz Alam ${ }^{1}$ \\ ${ }^{1}$ College of Pharmacy, Jazan University, P.O Box 114, Jazan, KSA, ${ }^{2}$ Department of Pharmacology, Faculty of Pharmacy, Jamia \\ Hamdard, (Hamdard Nagar), New Delhi-110 062, India
}

*For correspondence: Email: anwertarique25@yahoo.co.in; anwer.tariq@gmail.com Tel: +966-565772249; Fax: +96673217800

Received: 13 September 2014

Revised accepted: 18 December 2016

\begin{abstract}
Purpose: The present study was intended to investigate the preventive role ofWithania somnifera (WS) on hyperlipidemia and oxidative stress in the heart of streptozotocin (STZ)-induced type 2 diabetic rats. Methods: Single intraperitoneal injection of STZ $(100 \mathrm{mg} / \mathrm{kg})$ was given to 2 days rat pups to induce type 2 diabetes mellitus. Diabetes was confirmed 90 days after the administration of STZ by measuring blood glucose level. WS (200 and $400 \mathrm{mg} / \mathrm{kg}$ ) was administered orally once a day for 5 weeks after the confirmation of diabetes. Glucose, lactate dehydrogenase (LDH), creatinine kinase (CK), total cholesterol (TCh), triglycerides (TG), high density lipoprotein cholesterol (HDL-C), low density lipoprotein cholesterol (LDL-C), verylow density lipoprotein cholesterol (VLDL-C) and markers of oxidative stress parameters like lipid peroxidation (LPO), reduced glutathione (GSH), glutathione peroxidase $(G P x)$, glutathione reductase $(G R)$, glutathione-S-transferase (GST), superoxide dismutase (SOD) and catalase (CAT) were evaluated in the heart of type 2 diabetic rats.

Results: Oral administration of WS for 5 weeks resulted in a significant $(P<0.001)$ reduction in glucose, $L D H, C K, T C, T G, L D L-C, V L D L-C$ levels with significant elevation of HDL-C levels. On the other hand, WS treated diabetic rats significantly $(P<0.01-P<0.001)$ reduced the elevated levels of $L P O$, increased levels of antioxidant enzymes (i.e, GSH, GPX, GR, GST, SOD and CAT).

Conclusion: These findings propose the role of hyperlipidemia and cardiac oxidative stress in type 2 diabetic rats and suggested protective effect of WS in this animal model.
\end{abstract}

Keywords: Withania somnifera; Hyperlipidemia; Oxidative stress; Streptozotocin; Type 2 diabetes

Tropical Journal of Pharmaceutical Research is indexed by Science Citation Index (SciSearch), Scopus, International Pharmaceutical Abstract, Chemical Abstracts, Embase, Index Copernicus, EBSCO, African Index Medicus, JournalSeek, Journal Citation Reports/Science Edition, Directory of Open Access Journals (DOAJ), African Journal Online, Bioline International, Open-J-Gate and Pharmacy Abstracts

\section{INTRODUCTION}

Type 2 diabetes mellitus (DM) is one of the most common problems for the health care system, under which most of the patients with this disease are treated. Microvascular and microvascular complication is the primary cause of morbidity and mortality in both types of DM [1, 2]. It is believed that cardiac oxidative stress contributes to high incidence of cardiac dysfunction and mortality in type 2 DM [2]. For several years it has been suggested that patients with diabetes experience chronic oxidative stress which results from disturbance in the balance between the formation of free radicals in the body and scavenging of these radicals [3]. This can be appreciated by evaluation of cardiac oxidative stress parameters such as LPO, GSH, 
GPx, GR, GST, SOD and CAT in such patients. Previous reports from epidemiological and clinical studies have revealed that factors other than hyperglycemia are also important contributors in patients with diabetes, such as abnormalities in lipid and protein metabolism [4, 5]. Abnormalities in lipid metabolism are also seen in diabetic patients [6], nevertheless pharmacological investigations are needed in severe cases of hyperglycemia and hyperlipidemia [7].

Withania somnifera (WS) Dunal (family: Solanaceae), commonly known as ashwagandha is extensively used in Ayurvedic system of medicine [8]. Several studies on this plant revealed that it possesses anti-inflammatory, anti-tumor, anti-stress, anti-oxidant, immunomodulatory, hematopoietic and rejuvenating properties besides its positive influence on the endocrine, cardiopulmonary and central nervous system $[9,10]$. Recently we have published the protective effect of Withania somnifera against oxidative stress and pancreatic $\beta$-cell damage in type 2 diabetic rats [11]. Hence the present study was planned to investigate the preventive effect of WS on hyperlipidemia and oxidative stress in the heart of type 2 diabetic rats. The ultimate goal of the research was to demonstrate the therapeutic potential of WS in the treatment of type 2 diabetes mellitus.

\section{EXPERIMENTAL}

\section{Animals}

New born rat pups ( 2 days old) were used for this study. Pups and their mother were housed under ideal laboratory conditions, maintained on standard diet and water throughout the experimental period. The research study was approved by the Institutional Animal Ethics Committee (IAEC) of Jamia Hamdard, New Delhi, India and conducted as per the International guidelines for the care and use of laboratory animals [12].

\section{Drugs and Chemicals}

Aqueous root extract of Withania somnifera (Batch No. WS/05002) was a gift sample from Natural Remedies, Bangalore, India. It was supplied as standardized powder which contains withanolides $(3.9 \% \mathrm{w} / \mathrm{w})$. The extract was stored at $4{ }^{\circ} \mathrm{C}$ until used. Streptozotocin was procured from sigma chemicals (USA). Kits used in the study were purchased from Span Diagnostic Ltd, India. All other analytical grade chemicals were procured from well-known companies.

\section{Induction of type 2 diabetes mellitus}

Single intraperitoneal (i.p) injection of STZ (100 $\mathrm{mg} / \mathrm{kg}$ ) was given to 2 days old rat pups to induce type 2 diabetes mellitus [13]. Normal control rats received i.p injection of citrate buffer on the $2^{\text {nd }}$ day of their birth. All the surviving pups were kept with their mother till adulthood (mortality $\leq 30 \%$ ). Type 2 diabetes mellitus was confirmed 90 days after the administration of STZ by measuring blood glucose level. Animals with fasting glucose levels of $200 \mathrm{mg} / \mathrm{dl}$ or higher were deemed to be diabetic.

\section{Experimental design}

Five groups of rats were made with each group comprised six animals. The details of grouping made are given as follows:

Group-I: Normal control, received citrate buffer $(0.1 \mathrm{ml} / \mathrm{kg}$, i.p).

Group-II: Diabetic control (untreated), received STZ in a single dose (100 mg/kg, i.p).

Group-III: Only WS (400 mg/kg, p.o) for 5 weeks.

Group-IV: Diabetic + WS (200 mg/kg, p.o) for 5 weeks.

Group-V: Diabetic + WS (400 mg/kg, p.o) for 5 weeks.

\section{Biochemical estimations}

On the end of experiment blood samples were collected for biochemical estimation. Commercial diagnostic kits were used to estimate the glucose level in blood by glucose oxidase methods [14]. Serum was separated from whole blood and lipid profile parameters such as total cholesterol (TCh) [15], high density lipoprotein cholesterol (HDL-C) [16] and triglycerides [17] were estimated using diagnostic kits. Low density lipoprotein cholesterol (LDL-C) and very low density lipoprotein (VLDL-C) cholesterol were calculated by Friedwald et al equation[18]. The lactate dehydrogenase (LDH) and creatinine kinase (CK) was also estimated by using diagnostic kits $[19,20]$. Animals were sacrificed and heart was isolated, clean and washed with the cold normal saline. Further tissue was homogenized in buffer solution and tissue homogenate was used for MDA, Protein, GSH, GPx, GR, GST, SOD and CAT estimation. Lipid peroxidation (LPO) was measured by the reaction of thiobarbituric acid (TBA) with malondialdehyde (MDA) to yield a pink color complex which gives maximum absorbance at $535 \mathrm{~nm}$ due to the peroxidation of lipid membrane [21], whereas protein was estimated by the method of Lowery et al [22] using BSA as 
standard. GSH was estimated by the method of Jollow et al [23]. Glutathione peroxidase (GPx) and glutathione reductase (GR) were estimated by the oxidation of NADPH [24]. Glutathione-Stransferease (GST) was estimated by the method of Habig et al [25] using 1-Chloro-2,4 dinitrobenzene(CDNB) as substrate. SOD activity was expressed as units $\mathrm{mg}^{-1}$ protein and one unit of enzyme was defined as the enzyme activity that inhibits autoxidation of pyrogallol by $50 \%$ [26]. Catalase (CAT) was estimated by Claiborne procedure [27] using hydrogen peroxide $\left(\mathrm{H}_{2} \mathrm{O}_{2}\right)$ consumption at $240 \mathrm{~nm}$.

\section{Statistical Analysis}

All data were analyzed with help of Graph Pad Prism 5(Graph pad software Inc., USA). Data were expressed as the mean \pm standard error (S.E) and the mean value was compared by using one way analysis of variance (ANOVA) also followed by Tukey-Karmer test for multiple comparisons. $\mathrm{P} \leq 0.05$ was considered as statistically significant.

\section{RESULTS}

Effects of WS on hyperglycemia in type 2 diabetic rats

Blood glucose levels were significantly $(P<0.001)$ increased in diabetic control as compared to citrate control group (Table-1). The effects of WS on blood glucose level was significantly $(P<0.001)$ decreased in both doses $(200 \mathrm{mg} / \mathrm{kg}$ and $400 \mathrm{mg} / \mathrm{kg}$ ) when compared with diabetic control group.

\section{Effects of WS on LPO and GSH contents in type 2 diabetic rats}

The levels of malondialdehyde (MDA), a secondary product of lipid peroxides (LPO) and GSH contents in the homogenate of cardiac tissue is presented in Table 1. The levels of MDA was significantly $(P<0.001)$ increased whereas the contents of $G S H$ was significantly $(P<0.001)$ decreased in tissue homogenate of STZ treated diabetic control group as compare to citrate control group. WS treatment indicated that the both doses (200 and $400 \mathrm{mg} / \mathrm{kg}$ ) significantly $(P<0.01)$ decreased the elevated levels of MDA and increased the GSH contents in the tissue homogenate when compared with diabetic control rats.

\section{Effects of WS on lipid profile in type 2 diabetic rats}

The effect of WS on serum lipid profile is presented in Table 2. STZ treatment significantly increased the levels of TCh, TG, LDL-C, and

Table 1: Levels of blood glucose, lipid peroxidation (LPO) and reduced glutathione (GSH) contents in normal control, diabetic control and diabetic treated rats

\begin{tabular}{|c|c|c|c|c|}
\hline Groups & Treatment & $\begin{array}{l}\text { Blood Glucose } \\
\text { (mg/ dl) }\end{array}$ & $\begin{array}{l}\text { nmol TBARS formed/h } \\
\text { /mg protein) }\end{array}$ & $\begin{array}{l}\text { GSH }(\mu \mathrm{mol} / \mathrm{mg} \\
\text { protein) }\end{array}$ \\
\hline I & $\begin{array}{l}\text { Normal control } \\
\text { buffer, } 0.1 \mathrm{ml} / \mathrm{kg} \text {, i.p) }\end{array} \quad$ (citrate & $87.99 \pm 3.97$ & $0.812 \pm 0.05$ & $1.58 \pm 0.055$ \\
\hline II & $\begin{array}{l}\text { Diabetic control (STZ, } 100 \\
\mathrm{mg} / \mathrm{kg} \text {, i.p) }\end{array}$ & $279.94 \pm 8.09 "$ & $1.34 \pm 0.056$ & $0.945 \pm 0.054$ \\
\hline III & Only WS (400 mg/kg, p.o) & $85.93 \pm 3.06$ & $0.794 \pm 0.066$ & $1.70 \pm 0.08$ \\
\hline IV & Diabetic + WS (200 mg/kg, p.o) & $150.93 \pm 2.59^{y}$ & $1.19 \pm 0.041^{x}$ & $1.11 \pm 0.032^{x}$ \\
\hline V & Diabetic + WS (400 mg/kg, p.o) & $120.75 \pm 2.56^{y}$ & $1.04 \pm 0.043^{y}$ & $1.35 \pm 0.049^{y}$ \\
\hline
\end{tabular}

Table 2: Levels of lipid profile in normal control, diabetic control and diabetic treated rats

\begin{tabular}{|c|c|c|c|c|c|c|}
\hline Groups & Treatment & TCh (mg/dl) & $\begin{array}{c}\mathrm{HDL} \\
\text { (mg/dl) }\end{array}$ & TG (mg/dl) & LDL & VLDL \\
\hline I & $\begin{array}{l}\text { Normal control (citrate } \\
\text { buffer, } 0.1 \mathrm{ml} / \mathrm{kg} \text {, i.p) }\end{array}$ & $78.85 \pm 1.13$ & $35.12 \pm 1.39$ & $86.47 \pm 2.55$ & $26.84 \pm 1.21$ & $17.29 \pm 0.51$ \\
\hline II & $\begin{array}{l}\text { Diabetic control (STZ, } 100 \\
\mathrm{mg} / \mathrm{kg}, \text { i.p) }\end{array}$ & $183.45 \pm 1.54^{\pi \pi}$ & $22.78 \pm 0.73^{\pi \times}$ & $171.56 \pm 3.24^{* \pi}$ & $126.47 \pm 3.76^{\pi \times}$ & $34.2 \pm 0.45^{\pi \pi}$ \\
\hline III & Only WS (400 mg/kg, p.o) & $75.29 \pm 1.36$ & $35.46 \pm 0.72$ & $84.55 \pm 2.73$ & $22.92 \pm 1.46$ & $16.91 \pm 0.60$ \\
\hline IV & Diabetic + WS (200 mg/kg, p.o) & $130.86 \pm 1.93^{y}$ & $25.68 \pm 0.59^{y}$ & $134.97 \pm 1.47^{y}$ & $78.01 \pm 2.12^{y}$ & $26.99 \pm 1.39^{y}$ \\
\hline V & Diabetic + WS (400 mg/kg, p.o) & $108.05 \pm 1.86^{y}$ & $29.99 \pm 1.31^{y}$ & $110.29 \pm 1.48^{y}$ & $56.01 \pm 1.87^{y}$ & $22.05 \pm 1.29^{y}$ \\
\hline
\end{tabular}


VLDL-C and decreased HDL-C in diabetic control group when compared with normal control group. Oral administration of WS revealed that the both doses $(200$ and $400 \mathrm{mg} / \mathrm{kg})$ significantly $(\mathrm{P}<0.001)$ decreased the levels of TCh, TG, LDL$C$, and VLDL-C in serum when compared with diabetic control group. There was significant $(P<0.001)$ increase in the HDL-C levels in diabetic rats treated with WS 200 and 400 $\mathrm{mg} / \mathrm{kg}$ ) as compared to diabetic control.

\section{Effect of WS on serum levels of LDH and CK}

The activities of serum marker enzymes namely, $\mathrm{LDH}$ and CK were significantly increased in diabetic control groups as compared to normal control groups as presented in Figure 1. The elevated levels of $\mathrm{LDH}$ and $\mathrm{CK}$ were significantly $(P<0.001)$ decreased after the administration of WS $(200$ and $400 \mathrm{mg} / \mathrm{kg}$ ) in diabetic treated rats when compared with diabetic control group.

\section{Effects of WS on antioxidant enzymes (AOE) levels}

The levels of antioxidant enzymes (GPx, GR, GST, SOD and CAT) are presented in Table 3 in the cardiac tissue of normal control, diabetic
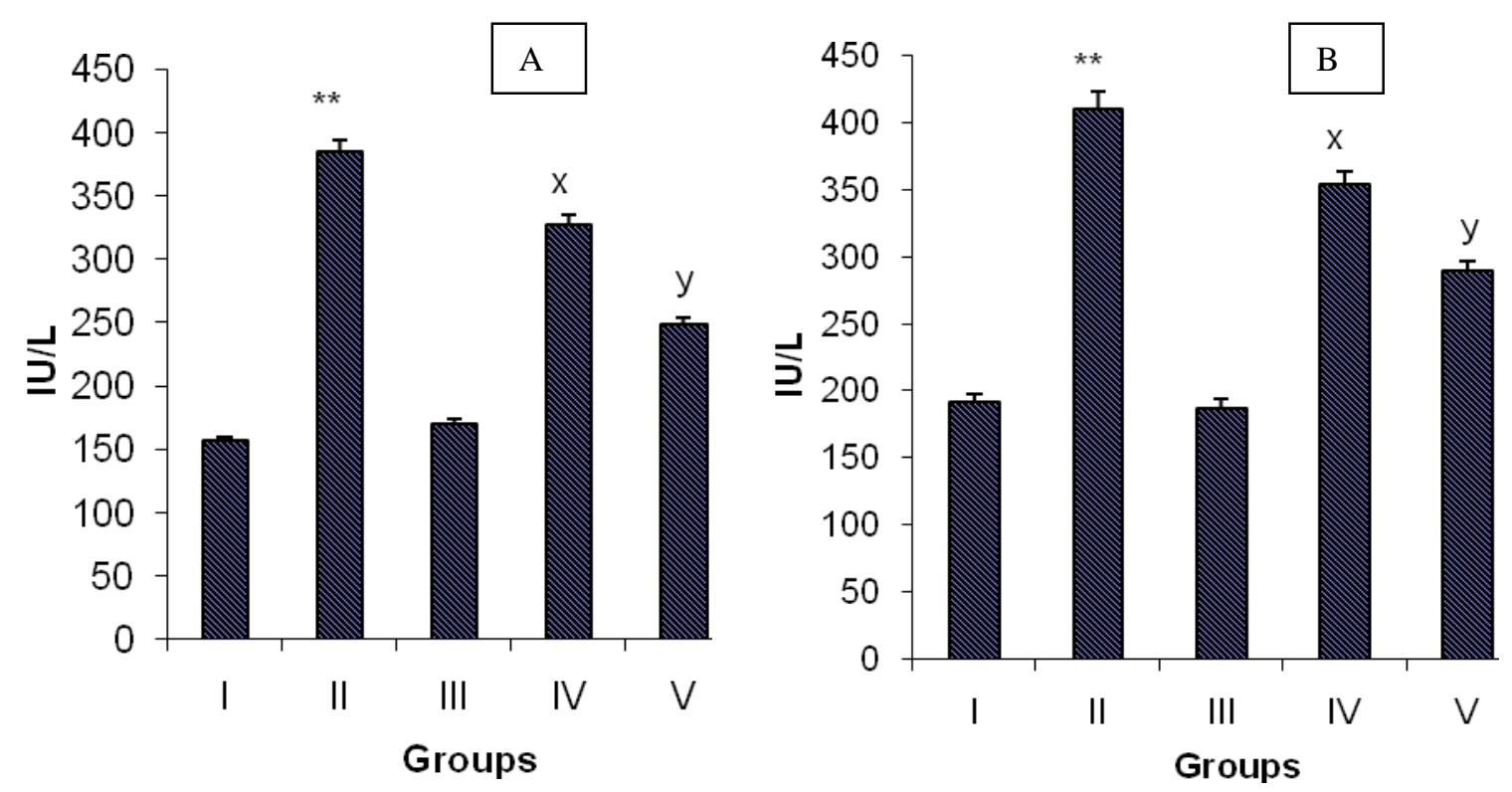

Figure 1: The activities of cardiac serum marker enzymes $(A=L D H$ and $B=C K)$ in normal control, diabetic control and diabetic treated rats. Data are expressed in mean $\pm \operatorname{SEM}(n=6)$. $P<0.05$ is statistically significant. The results were compared with ${ }^{* *}$ normal control group, ${ }^{x, y}$ diabetic control group

Table 3: Activities of antioxidant enzymes (such as GPx, GR, GST, SOD and CAT) in the heart of normal control, diabetic control and diabetic treated rats

\begin{tabular}{|c|c|c|c|c|c|c|}
\hline Groups & Treatment & $\begin{array}{c}\text { GPX } \\
\text { (nmol NADPH } \\
\text { oxidized/min/ } \\
\text { mg protein) }\end{array}$ & $\begin{array}{c}\text { GR } \\
\text { (nmol NADPH } \\
\text { oxidized/min/mg } \\
\text { protein) }\end{array}$ & $\begin{array}{c}\text { GST } \\
\text { (nmol CDNB } \\
\text { conjugates } \\
\text { formed } / \mathrm{min} / \mathrm{m} \\
\text { g protein) } \\
\end{array}$ & $\begin{array}{l}\text { SOD } \\
\text { (Units/mg } \\
\text { protein) }\end{array}$ & $\begin{array}{c}\text { CAT } \\
\text { (nmol } \mathrm{H}_{2} \mathrm{O}_{2} \\
\text { consumed } \\
\text { min }^{-1} \mathrm{mg}^{-1} \\
\text { protein) }\end{array}$ \\
\hline $\mathbf{I}$ & $\begin{array}{l}\text { Normal control } \\
\text { (Citrate buffer, } \\
0.1 \mathrm{ml} / \mathrm{kg} \text {, i.p) }\end{array}$ & $221.07 \pm 7.70$ & $358.57 \pm 8.20$ & $361.51 \pm 8.82$ & $15.21 \pm 0.87$ & $139.53 \pm 9.01$ \\
\hline II & $\begin{array}{lr}\text { Diabetic control } \\
\text { (STZ, } & 100 \\
\mathrm{mg} / \mathrm{kg}, \text { i.p) } & \end{array}$ & $156.94 \pm 9.46$ & $265.39 \pm 7.55^{\wedge}$ & $286.97 \pm 6.85^{\wedge \prime}$ & $6.94 \pm 0.48^{n \prime}$ & $68.20 \pm 2.57^{n}$ \\
\hline III & $\begin{array}{l}\text { Only WS (400 } \\
\mathrm{mg} / \mathrm{kg}, \mathrm{p} . \mathrm{o})\end{array}$ & $220.86 \pm 13.86$ & $361.64 \pm 9.97$ & $353.14 \pm 6.48$ & $14.44 \pm 0.50$ & $135.50 \pm 8.27$ \\
\hline IV & $\begin{array}{l}\text { Diabetic }+ \text { WS } \\
(200 \mathrm{mg} / \mathrm{kg}, \text { p.o })\end{array}$ & $180.35 \pm 9.77^{x}$ & $284.27 \pm 5.50^{x}$ & $309.07 \pm 8.30^{x}$ & $8.41 \pm 0.29^{y}$ & $83.97 \pm 3.05^{x}$ \\
\hline V & $\begin{array}{l}\text { Diabetic }+ \text { WS } \\
(400 \mathrm{mg} / \mathrm{kg}, \text { p.o })\end{array}$ & $194.75 \pm 6.97^{y}$ & $320.92 \pm 4.99^{y}$ & $332.07 \pm 6.13^{y}$ & $y_{y} 11.08 \pm 0.44$ & ${ }_{y}^{107.46 \pm 3.62}$ \\
\hline
\end{tabular}

Trop J Pharm Res, January 2017; 16(1): 122 
control and WS treated diabetic rats. STZ treated diabetic control group showed significant reduction in the levels of these enzymes. Treatment with WS $(200$ and $400 \mathrm{mg} / \mathrm{kg})$ significantly $(P<0.001)$ improved the levels of these antioxidant enzyme in diabetic rats in a dose dependent manner when compared to diabetic control rats.

\section{DISCUSSION}

Cardiovascular disease (CVD) is the primary cause of mortality in both type of diabetes mellitus. Hyperlipidemia is one of the most important cardiovascular risk factors among patients with type 2 diabetes [28]. The American Diabetes Association (ADA) recommends forceful targets for lipid management in patients with type 2 diabetes [29]. Therefore, it is very important to treat hyperlipidemia in order to reduce the incidence of cardiovascular disease. The results obtained from our research study exhibited that STZ treated diabetic rats indicated clear-cut abnormalities in glucose and lipid metabolism as substantiated from the significant elevation of blood glucose, serum TCh, TG, LDL$C$, VLDL-C and reduction of HDL-C levels. In the present study WS (200 \& $400 \mathrm{mg} / \mathrm{kg})$ treatment for 5 weeks was sufficient to produce a significant reduction in the levels of blood glucose, TCh, TG, LDL-C, VLDL-C and significant increase in HDL-C levels in diabetic rats.

The cardiotoxicity of xenobiotics can be evaluated by quantifying the activity of cardiac marker enzymes. Serum LDH and CK, which are distributed all over the body, possess isoenzymes that are recognized as markers for liver muscle and heart lesion [30]. Conflicting reports are available in the literature on the relationship between diabetes and creatinine kinase activity [31]. The increased activity of enzymes such as LDH and CK in serum of type 2 diabetic control rats exposed the myocardial damage produced after the induction of diabetes. The activities of $\mathrm{LDH}$ and $\mathrm{CK}$ were re-established by treatment with WS, thus exhibiting muscle integrity and decrease in myocardial damage in diabetic rats. The decreased activities of $\mathrm{LDH}$ and CK might be due to decreased leakage of these enzymes from the tissue bed to serum.

Hyperglycemia accelerates the production of reactive oxygen species (ROS), leading to oxidative myocardial injury [32]. The ROS bring about an upsurge in mitochondrial superoxide anion production, glucose auto-oxidation and cardiac lipid peroxidation on exposure to an oxidative stress.Development of diabetic complications may be due to the overproduction of ROS. When the generation of ROS surpasses the threshold of the cells to detoxify them, oxidative stress develops, which is damaging to the integrity of biological tissue. Therefore, we hypothesize that inhibition of myocardial stress would lead to the suppression of myocardial cell death in type 2 diabetes.

The elevated level of LPO is attributed to the enhanced production of ROS. In the present study we found significant increase in MDA formation, an index for LPO in the heart of type 2 diabetic rats. The WS supplementation to such rats exhibited significant decrease in the levels of LPO indicating probable role in scavenging hydroxyl and peroxyl radicals generated by STZ. It is well known that increased level of glutathione (GSH) protect cellular system against toxic effect of lipid peroxidation. Previous research studies suggest that antioxidants that maintain the concentration of $\mathrm{GSH}$ restore cellular defensemechanism, block lipid peroxidation and protect tissue against oxidative damage. A recent study [33] also revealed that mitochondrial oxidative stress such as GSH depletion is noticeable cause of cardiac death under diabetic condition. The contents of GSH decreased in the heart of type 2 diabetic rats. Furthermore, WS treatment exhibited significant increase in GSH contents in the heart of type 2 diabetic rats.

STZ treatment resulted in significant decrease in the levels of antioxidant enzymes (i.e., GPx, GR, GST, SOD and CAT). Previous studies demonstrated that GPx decreases hydroperoxides to water by utilizing hydrogen from reduced glutathione (GSH). In this process the reduced glutathione is oxidized (GSSG) after donating proton. GR utilizes NADPH and reduces the oxidized glutathione (GSSG) back to the GSH. The observed decreased activities of GPX, GR and GST in the present study might be due the decreased level of GSH. This decrease in GSH levels might be due to its increased utilization by GPx, inhibition of its regenerating enzyme GR and the direct reaction between GSH and ROS generated by STZ. In the present study, we have ascertained that WS potentiates the antioxidative system and improved the levels of GSH dependent enzymes such as GPx, GR and GST in the heart of type 2 diabetic rats. We found that STZ treatment decreased the activities of SOD and CAT in cardiac tissue owing to surplus availability of superoxide anion $\left(\mathrm{O}_{2}^{-}{ }^{-}\right)$and $\mathrm{H}_{2} \mathrm{O}_{2}$ in the biological system. This in turn generates hydroxyl and peroxyl radicals resulting in the beginning and proliferation of lipid peroxidation. WS treatment indicated a 
significant increase in the levels of SOD and CAT in the cardiac tissue of type 2 diabetic rats.

\section{CONCLUSION}

Results of the present study indicate that WS supplementation may block many complications of diabetes by controlling oxidative stress and hyperlipidemia and thus protects heart from damage. If this protective function is confirmed after clinical studies in type 2 diabetic patients, WS would be beneficial in the treatment of hyperlipidemia and suppression of myocardial cell death.

\section{DECLARATIONS}

\section{Conflict of Interest}

No conflict of interest associated with this work.

\section{Contribution of Authors}

The authors declare that this work was done by the authors named in this article and all liabilities pertaining to claims relating to the content of this article will be borne by them.

\section{Open Access}

This is an Open Access article that uses a funding model which does not charge readers or their institutions for access and distributed under the terms of the Creative Commons Attribution License (http://creativecommons.org/licenses/by 14.0) and the Budapest Open Access Initiative (http://www.budapestopenaccessinitiative.org/rea d), which permit unrestricted use, distribution, and reproduction in any medium, provided the original work is properly credited.

\section{REFERENCES}

1. Reusch JE, Draznin BB. Atherosclerosis in diabetes and insulin resistance. Diabetes Obes Metab 2007; 9 (4): 455-463.

2. Trost S, LeWinter M. Diabetic cardiomyopathy. Curr Treat Options Cardiovasc Med 2001; 3: 481-492.

3. Vural H, Sabuncu T, Arslan SO, Aksoy N. Melatonin inhibits lipid peroxidation and stimulates the antioxidant status of diabetic rats. J Pineal Res 2001; 31: 193-198.

4. Niemeijer-Kanters SD, Banga JD, Erkelens DW. Lipid lowering therapy in diabetes mellitus. Neth $J$ Med 2001; 58(5): 214-222.

5. Franco $\mathrm{OH}$, Steyerberg EW, Hu FB, Mackenbach J, Nusselder W. Associations of diabetes mellitus with total life expectancy and life expectancy with and without cardiovascular disease. Arch Intern Med 2007; 167(11): 1145-1151.

6. Godi R, Samaha FF. Dyslipidemia in type 2 diabetes mellitus. Curr Diab Rep 2007; 7(3): 228-234.
7. Brunzell JD, Ayyobi AF. Dyslipidaemia in the metabolic syndrome and type 2 diabetes mellitus. Am J Med 2003; 115: 24S-28S.

8. Sangwan, RS, Chaurasiya ND, Lal P, MisraL, Uniyal GC, Tuli R., Sangwan NS. Withanolide A Biogeneration in in-vitro shoot cultures of ashwagandha (Withania somnifera DUNAL), a medicinal plant in ayurveda. Chem Pharm Bull 2007; 55(9): 1371-1375.

9. Widodo N, Priyandoko D, Shah N, Wadhwa R, Kaul SC. Selective killing of cancer cells by ashwagandha leaf extract and its component withanone involves ROS signaling. Plos One 2010; 5 (10): e13536-e13537.

10. Mishra L, Singh BB, Dagenais S. Scientific basis for the therapeutic use of Withania somnifera (Ashwagandha): a review. Alter Med Rev 2000; 5: 334-346.

11. Anwer T, Sharma M, Pillai KK, Khan G. Protective effect of Withania Somnifera against oxidative stress and pancreatic $\beta$-cell damage in type 2 diabetic rats. Acta Pol Pharma Drug Res 2012; 69(6): 1095-1101.

12. NRC [National Research Council]. 1996. Guide for the Care and Use ofLaboratory Animals. 7th ed. Washington DC: National Academy Press.

13. Shinde UA, Goyal RK. Effect of chromium picolinate on histopathological alterations in STZ and neonatal STZ diabetic rats. J Cell Mol Med 2003; 7(3): 322329.

14. Braham D, Trinder P. An improved colour reaction for the determination of blood glucose by oxidase system. Analyst 1972; 97: 142-144.

15. Wybenga DR, Pileggi VJ, Dirstine PH, Di Glorgio J. Direct manual determination of serum total cholesterol with a single stable reagent. Clin Chem 1970; 16: 980984.

16. Warnick GR, Nguyen T, Albers AA. Comparison of improved precipitation methods for quantification of high-density lipoprotein cholesterol. Clin Chem 1985; 31: 217-22.

17. Bucolo G, David M. Quantitative determination of serum triglycerides by use of enzymes. Clin Chem 1973; 19: 476-82.

18. Friedewald WT, Levy RL, Fredrickson DS. Estimation of the concentration of low-density lipoprotein cholesterol in plasma without use of the preparative ultracentrifuge. Clin Chem 1972; 18: 499-502.

19. Lum G, Gambino SR. A comparison of serum versus heparinized plasma for routine chemistry tests. Am J Clin Pathol 1974; 61: 108 - 113.

20. Tsung SH. Creatine kinase activity and isoenzyme pattern in various normal tissues and neoplasms. Clin Chem 1983; 29: 2040 - 2043.

21. Ohkawa H, Ohishi N, Yagi K. Assay of lipid peroxides in animal tissues by thiobarbituric acid reaction. Anal Biochem 1979;95: 351-358.

22. Lowry $\mathrm{OH}$, Rosenbrough NJ, Forr AL, Randall RJ. Protein measurements with the Folin's reagent. J Biol Chem 1951; 193: 265-275.

23. Jollow DW, Mitchell JR, Zampagilone $N$, Gilete $R$. Bromobenzene induced liver necrosis: Protective role of glutathione and evidence for 3, 4-bromobenzene oxide as the hepatotoxic intermediate. Pharmacology 1974; 11: 151-169.

24. Haque R, Bin-Hafeez B, Parvez S, Pandey S, Ahmad I, Raisuddin S. Aqueous extract of walnut (Juglansregia L.,) protects mice against cyclophosphamide-induced biochemical toxicity. Hum ExpToxicol 2003; 22: 473480.

25. Habig WH, Pabst MJ, Jakoby WB. Glutathione-Stransferase. The first enzymatic step in mercapturic acid formation. J BiolChem 1974; 249: 7130-7139.

26. Marklund S, Marklund G. Involvement of the superoxide anion radical in the auto-oxidation of pyrogallol and a convenient assay for superoxide dismutase. Eur $J$ Biochem 1974; 47: 469-474. 
27. Claiborne A. Catalase activity. In: Greenwald, R.A (Ed.). CRC Handbook of Methods for Oxygen Radical Research 1985. CRC Press, Boca Raton, FL, pp. 283-284.

28. Schwartz SL. Diabetes and dyslipidaemia. Diabetes Obes Metab 2006; 8(4): 355-364.

29. American Diabetes Association. Diagnosis and classification of diabetes mellitus. Diabetes Care 2005; 28(1): S37-S42.

30. Jain $N$, Vijayaraghavan $R$, Pant SC, Lomash V, Ali $M$. Aloe vera gel alleviates cardiotoxicity in streptozocin induced diabetes in rats. J Pharm Pharmacol 2010; 62: 115-123.
31. Zhao X, Bassirat M, Zeinab $K$, Helme RD. Effect of diabetes on creatine kinase activity in streptozotocin diabetic rats. Chin Med J 1999; 112(11): 1028-1031.

32. Penckofer S, Schwertz D, Florczak K. Oxidative stress and cardiovascular disease in type 2 diabetes: the role of antioxidants and pro-oxidants. J Cardiovasc Nurs 2002; 16: 68-85.

33. Ghosh S, Pulinikunnil T, Yuen G. Cardiomyocyte apoptosis induced by short-term diabetes requires mitochondrial GSH depletion. Am J Physiol Heart Circ Physiol 2005; 289: 768-776. 